\title{
Distribution and Speciation of Heavy Metals in Soils around Some Selected Auto Repair Workshops in Oghara, Delta State, Nigeria.
}

\author{
B. Anegbe ${ }^{1}$, J.M. Okuo 2 , M. Atenaga ${ }^{3}$, A. Ighodaro ${ }^{2}$, A. Emina. ${ }^{2}$, N.A. Oladejo ${ }^{2}$ \\ ${ }^{1}$ Department of Basic and Industrial Chemistry, Western Delta University, P.M.B. 10, Oghara, Delta State. \\ ${ }^{2}$ Environmental Analytical Research Laboratory, Department of Chemistry, University of Benin, Benin City, Nigeria. \\ ${ }^{3}$ Department of Physics with Electronics, Western Delta University, P.M.B. 10, Oghara, Delta State.
}

\begin{abstract}
Soil contamination by heavy metals is a worldwide environmental problem. Hence determining the chemical forms of a metal in soils is important to evaluate its mobility and bioavailability. This study determined the distribution and speciation of some heavy metals ( $\mathrm{Fe}, \mathrm{Cu}, \mathrm{Zn}, \mathrm{Pb}$ and $\mathrm{Cd}$ ) in soils around some selected auto repair workshops in Oghara, Delta State, Nigeria. Soil samples were collected with the aid of soil Augar within a depth of $0-15 \mathrm{~cm}$ from the vicinity of the four selected auto repair workshops in Oghara, Delta State, Nigeria. The control samples were taken from a site free from auto repair and commercial activities. The soil samples were assessed for some physico-chemical properties, total heavy metal concentration, chemical speciation, mobility and some metal assessment indices of the heavy metals as a function of soil properties. The mean concentration of $\mathrm{Fe}, \mathrm{Cu}, \mathrm{Zn}, \mathrm{Pb}$ and $\mathrm{Cd}$ in all the sites analyzed were 550.54, 31.08, 36.15, 4.21 and 1.11 $\mathrm{mg} / \mathrm{kg}$ respectively. Site $B$ and the control had the highest and lowest total concentration of the five metals analyzed respectively. The levels of $\mathrm{Cu}$ were above the DPR target value in sites $A$ and $B$, while the levels of $C d$ were above the target value in all the sites except in the control site. All the metals were found to be mostly concentrated in the residual fraction except $Z n$ which was found mostly in the carbonate fraction. The mobility factors revealed that $\mathrm{Zn}$ is the most mobile element with an average mobility factor of $41.54 \%$ while $\mathrm{Cd}$ is the least mobile element with an average mobility factor of $16.51 \%$. Contamination factors, index of geoaccumulation and pollution load index were also calculated. This study showed that mechanic workshop is one of the major sources of anthropogenic heavy metals concentration in the environment.
\end{abstract}

Keywords- Soil, Heavy Metals, Speciation, Bioavailability, Mobility.

\section{INTRODUCTION}

It has been widely accepted that soil plays a key role in sustaining life in earth's ecosystems (Young and
Crawford, 2004). The very survival of mankind is tied on its productivity as a medium for plants to grow (KabataPendias and Mukherjee, 2007). Heavy metals emanating from anthropogenic Automobiles introduce a number of toxic metals into the environment. Also the wear of auto tires, degradation of parts, grease, peeling paint and metal in auto-catalysts are sources of heavy metal pollution (Pecheyran et al., 2000). This has led to elevated levels of heavy metals in automobile mechanic workshop soils (Ipeaiyeda and Dawodu, 2008; Iwegbue, 2007). This implies that water bodies (surface and ground water) within and away from the automobile mechanic workshops may equally be polluted with these metals due to continuous interactions between soil and water and the high dispersion rate (Nwachukwu et al., 2010). The fate of the various heavy metals and metalloids in the automobile mechanic workshops is of great concern because soil, water and dust in these areas may contain higher than average abundance of these elements, which may cause the formation of the more available forms of these elements (Adriano, 1992). In recent years there has been increased interest in the studies on speciation or chemical forms of heavy metals in polluted soils and sediments using sequential extraction techniques because these provide knowledge on metal affinity to soil components and the strength with which they are bound to matrix (Norvell, 1984). The use of sequential extractions, although time consuming, furnishes detailed information about the origin, mode of occurrence, biological and physicochemical availability, mobilization and transport of trace metals (Ure and Davidson, 2002). Sequential extraction procedures selectively extract metals bound by specific soil fractions with minimal effects on the soil components. In practice, sequential fractionation schemes have been suggested to identify element distribution with operationally defined soil pools (Amanda and Weindorf, 2010). As a result of ineffective law enforcement agencies to enforce existing environmental laws coupled with lack of stringency even when attempts are made to enforce, Nigerian citizens and 
indeed residents of Oghara and environs in Delta State continue to dump refuse and litter the environment indiscriminately with such toxic substances as condemned engine oil, car batteries from mechanic workshop and solid waste even on the streets. These heavy metals can become a threat to vegetation and animals and ultimately affects the quality of human life, Thus, it becomes imperative to assess the levels of physico-chemical properties, spatial distribution and chemical speciation of heavy metals in soil from auto-repair workshops in Oghara and its environs in Delta State, Nigeria in order to determine their potential hazards to humans.

\section{MATERIALS AND METHODS}

\section{Study Area}

Oghara is a town in Ethiope West Local Government Area of Delta State, Nigeria and is located between latitude $5^{0} 35^{\prime} 1^{\prime \prime} \mathrm{N}$ and longitude $5^{0} 51^{\prime} 16^{\prime}$ 'E. the city has road intersections connecting Sapele to Warri and Benin. This study was conducted in four popular automobile workshops in within the town Oghara, site selection was based on the distance from one another, and all samples were collected within the range of latitude $5^{0} 55^{1} 54 \mathrm{~N}$ to $5^{0} 57^{\mathrm{l}} 11 \mathrm{~N}$ and longitude $5^{0} 38^{\mathrm{l}} 40 \mathrm{E}$ to $5^{0} 41^{1} 19 \mathrm{E}$. Global positioning system (GPS) and ground reconnaissance were used for identification of sites and geo-referencing.

Table.1: Showing Site Code, Coordinates and Site Description

\begin{tabular}{|l|l|l|}
\hline Site Code & \multicolumn{1}{|c|}{ Coordinates } & Site Description \\
\hline Site $\mathbf{1}$ & Lat- 5.95353, Long- 5.63913 & This site is located along community road Ogareki-oghara \\
\hline Site $\mathbf{2}$ & Lat- 5.93487, Long- 5.67913 & This site is located beside Ibori round about, Oghara. \\
\hline Site 3 & Lat- 5.94260, Long-5.68670 & This site is located at the express. \\
\hline Site 4 & Lat -5.93819, Long- 5.65704 & This site is located at Volts electrical company. \\
\hline
\end{tabular}

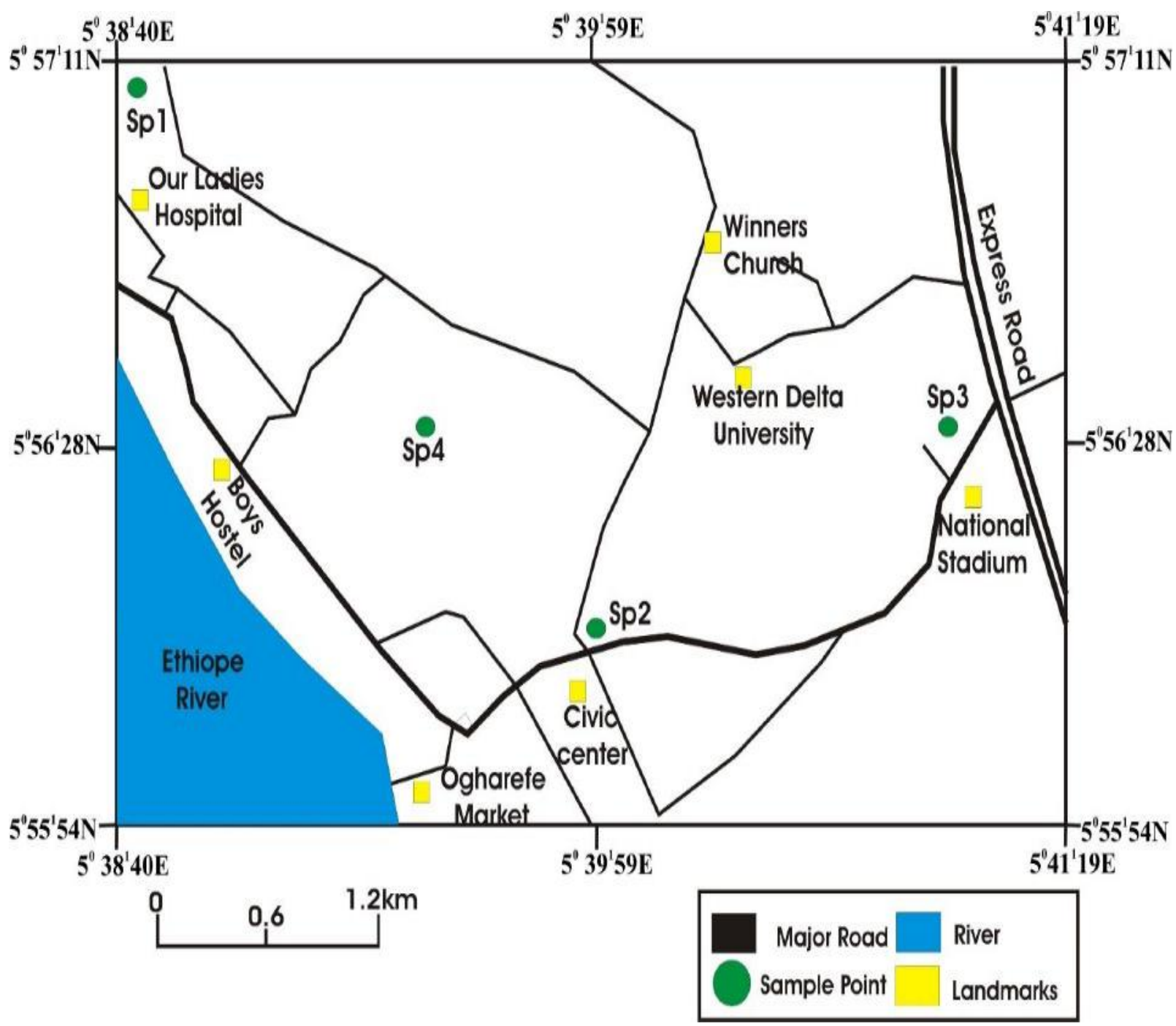

Fig.1: Map of Oghara Showing the Sampled Sites 


\section{Collection of Soil Samples}

Topsoil $(0-15 \mathrm{~cm})$ samples were collected from five (5) different mechanic workshops in Oghara. At each site, three different points were chosen using cluster random sampling technique to collect the sample with the aid of soil auger, and then blended (mixed) to obtain a representative sample. Control sample was also collected from a site where there are neither car repairs nor commercial activities carried out. The collected samples were transferred into a black polythene bag, properly labelled and transported to laboratory (Tripathi and Misra, 2012). All samples were air dried and ground to pass through a $2 \mathrm{~mm}$ sieve and used for both physico-chemical analysis and fractionation experiment (Anegbe and Okuo, 2013).

\section{Physico-chemical Analysis of the Soil Samples}

The $\mathrm{pH}$ and the CEC were determined as described by Anegbe and Okuo (2013). The hydrometer method described by Asagba et al. (2007) was used in evaluating the particle size. The concentration of phosphorus was obtained by the Oviasogie et al. (2006) method. The nitrogen content was determined by colorimetric method (Vogel, 2008). The method described by Anegbe et al. (2017) was used to determine the organic carbon content, while the total heavy metals determination was carried out according to Okuo et al. (2016). The chemical fractionation was carried out as described by Anegbe et al., (2014). All glasswares used were soaked and washed with chromic acid and rinsed with distilled water. Bulk scientific standard solution was used to calibrate the Atomic Absorption Spectrometer (Pg A500 model). Procedural blank samples were subjected to similar extraction method using the same amount of reagents.

\section{RESULTS AND DISCUSSION}

The physico-chemical properties of the soil samples at various sites are shown in Table 2 .

Soil $\mathrm{pH}$ is the most widely accepted parameter which exerts a controlling influence on the availability of micronutrients and heavy metals in the soil to plants (Igwe et al., 2005). The $\mathrm{pH}$ values of the soil samples from the automobile workshops were found to be in the acidic region $(5.10-5.40)$ and lower than that of the control (6.40). Acidity controls availability, mobility and toxicity of heavy metal ions in the soils. Most metals tend to be less mobile in soil with high $\mathrm{pH}$ as they tend to form insoluble complexes (Anegbe et al., 2014). Electrical conductivity measures soil salinity. The electrical conductivities of the soil samples from the automobile workshops were all higher than that of the control. This indicates that movement of charge particles would be more at the workshops than that of the control because there are more soluble salts in the soil samples from the automobile workshops than the control (Karaca, 2004; Arias et al., 2005).

Table.2: Physico-chemical Properties of the Soil Samples from the Sites

\begin{tabular}{|c|c|c|c|c|c|c|c|c|c|c|c|c|c|c|}
\hline Site & $\mathbf{P h}$ & $\begin{array}{l}\text { EC } \\
(\mu \mathrm{s} / \mathbf{c} \\
\mathbf{m})\end{array}$ & $\begin{array}{l}\mathbf{N} \\
(\mathrm{mg} / \mathrm{k} \\
\mathrm{g})\end{array}$ & $\begin{array}{l}P \\
(\mathrm{mg} / \mathrm{k} \\
\mathrm{g})\end{array}$ & $\begin{array}{l}\text { Ca } \\
(\mathrm{Cmol} \\
/ \mathrm{kg})\end{array}$ & $\begin{array}{l}\text { Mg } \\
\text { (Cmol/ } \\
\text { kg) }\end{array}$ & \begin{tabular}{|l|}
$\mathrm{Na}$ \\
$(\mathrm{Cmol} /$ \\
$\mathrm{kg})$
\end{tabular} & \begin{tabular}{|l|}
$K$ \\
$(\mathbf{C m}$ \\
ol/kg \\
) \\
\end{tabular} & $\begin{array}{l}\text { CEC } \\
(\mathrm{Cmol} \\
/ \mathrm{kg})\end{array}$ & $\begin{array}{l}\text { O.C } \\
(\%)\end{array}$ & $\begin{array}{l}\text { O. } \\
\text { M } \\
(\% \\
)\end{array}$ & $\begin{array}{l}\text { SA } \\
\text { ND } \\
(\%)\end{array}$ & $\begin{array}{l}\text { SILT } \\
(\%)\end{array}$ & $\begin{array}{l}\text { CL } \\
\text { AY } \\
(\%)\end{array}$ \\
\hline A & 5.40 & $\begin{array}{l}428 . \\
5\end{array}$ & 4.50 & 23.64 & 3.01 & 0.75 & 1.25 & 1.09 & 6.10 & 0.77 & $\begin{array}{l}1.3 \\
3\end{array}$ & $\begin{array}{l}74.2 \\
1\end{array}$ & 23.40 & 2.39 \\
\hline B & 5.10 & $\begin{array}{l}356 . \\
0\end{array}$ & 5.50 & 32.60 & 1.09 & 0.98 & 1.08 & 0.98 & 4.13 & 0.99 & $\begin{array}{l}1.7 \\
1\end{array}$ & $\begin{array}{l}72.6 \\
2\end{array}$ & 24.40 & 2.98 \\
\hline $\mathrm{C}$ & 5.10 & $\begin{array}{l}477 . \\
5\end{array}$ & 5.20 & 30.90 & 1.03 & 0.72 & \begin{tabular}{|l|}
1.02 \\
\end{tabular} & 0.94 & 3.71 & 0.95 & $\begin{array}{l}1.6 \\
4\end{array}$ & $\begin{array}{l}73.9 \\
1\end{array}$ & 23.90 & 2.19 \\
\hline $\mathrm{D}$ & 5.20 & $\begin{array}{l}426 . \\
5\end{array}$ & 3.20 & 21.00 & 1.51 & 0.67 & 0.91 & \begin{tabular}{|l|}
0.87 \\
\end{tabular} & 3.96 & 0.76 & $\begin{array}{l}1.3 \\
1\end{array}$ & $\begin{array}{l}75.4 \\
0\end{array}$ & 22.40 & 2.20 \\
\hline $\begin{array}{l}\text { Contr } \\
\text { ol }\end{array}$ & 6.40 & $\begin{array}{l}124 . \\
0\end{array}$ & 0.26 & 18.09 & 3.20 & 2.50 & 1.42 & 1.12 & 8.33 & 0.38 & $\begin{array}{l}0.6 \\
6\end{array}$ & $\begin{array}{l}78.6 \\
0\end{array}$ & 18.20 & 3.20 \\
\hline $\begin{array}{l}\mathrm{p}- \\
\text { value }\end{array}$ & $\begin{array}{l}0.00 \\
0 \\
\end{array}$ & $\begin{array}{l}0.00 \\
4 \\
\end{array}$ & 0.017 & 0.001 & 0.014 & 0.032 & 0.000 & 0.000 & 0.004 & $\begin{array}{l}0.00 \\
2 \\
\end{array}$ & $\begin{array}{l}0.0 \\
02 \\
\end{array}$ & $\begin{array}{ll}0.00 \\
0 \\
\end{array}$ & 0.000 & $\begin{array}{l}0.00 \\
0 \\
\end{array}$ \\
\hline
\end{tabular}

Organic matter acts as a major adsorbent for metals through the formation of chelates and renders them immobile (Lawan et al., 2012). The organic matter (OM) contents at the automobile workshops (1.31-1.71\%) were higher than the control $(0.66 \%)$. This might be due to the presence of many organic matter waste residues from effluent oil and oil spills at the automobile workshops which adds more organic matter and carbon, also leading to a higher organic carbon values of the sites. The $\mathrm{Ca}^{2+}$, $\mathrm{Mg}^{2+}, \mathrm{Na}^{+}$and $\mathrm{K}^{+}$of the soil samples from the automobile workshops were all lower than that of the control. the cation exchange capacity (CEC) values at the automobile 
workshops were quite low compared to the control (8.33 $\mathrm{Cmol} / \mathrm{kg}$ ). It was observed that at the automobile workshops, site C $(3.71 \mathrm{Cmol} / \mathrm{kg})$ and site A $(6.10$ $\mathrm{Cmol} / \mathrm{kg}$ ) had the lowest and highest CEC respectively. Soils with low CEC are more likely to develop deficiencies in potassium $\left(\mathrm{K}^{+}\right)$, magnesium $\left(\mathrm{Mg}^{2+}\right)$ and other cations, while high $\mathrm{CEC}$ soils are less susceptible to leaching of these cations (CUCE, 2007; Okiemen et al., 2012). The low values of the CEC were attributed to high sandy nature of the soil samples (Ugbune and Okuo, 2011). The $\mathrm{CEC}, \mathrm{Ca}^{2+}, \mathrm{Mg}^{2+}, \mathrm{Na}^{+}$and $\mathrm{K}^{+}$values reported in this research were all greater than those reported by Anegbe et al. (2014) in a similar research carried out in Benin City. As the texture of the soil plays a very important role in the plant species establishment and development and also influences physical parameters of the soil. The soil texture class of all the soil samples (automobile workshops and control) as represented in table 2 showed that they were all sandy soils with very high percentage of sand and had very low clay contents ranging from $2.19-3.20 \%$. Similar result was obtained by (Anegbe and Okuo, 2013). Soils with high sand content exceeding $70 \%$ will have weak surface aggregation and such soils will be porous and have high rate of water infiltration and air circulation (Gbadegesin and Abua, 2011). The nitrogen and phosphorus contents of the soil samples were both higher at the automobile workshop sites compared to the control. T-test was used to indicate significant difference between variables. Pvalues less than 0.05 were considered statistically significant.

Table.3: Total Metal Concentrations (in $\mathrm{mg} / \mathrm{kg}$ ) of the Heavy Metals in the Sites

\begin{tabular}{|l|c|c|c|c|c|l|}
\hline Sites & $\mathrm{Fe}$ & $\mathrm{Cu}$ & $\mathrm{Zn}$ & $\mathrm{Pb}$ & $\mathrm{Cd}$ & Total \\
\hline $\mathrm{A}$ & 530.80 & 37.44 & 35.81 & 3.67 & 0.87 & 608.59 \\
\hline $\mathrm{B}$ & 714.20 & 44.35 & 39.35 & 6.17 & 1.05 & 805.12 \\
\hline $\mathrm{C}$ & 683.90 & 30.55 & 41.38 & 5.28 & 0.99 & 762.1 \\
\hline $\mathrm{D}$ & 560.80 & 28.26 & 48.42 & 3.96 & 2.55 & 643.99 \\
\hline Control & 263.00 & 14.80 & 15.79 & 1.98 & 0.08 & 295.65 \\
\hline Average & 550.54 & 31.08 & 36.15 & 4.21 & 1.11 & \\
\hline P-value & 0.002 & 0.003 & 0.003 & 0.004 & 0.051 & \\
\hline
\end{tabular}

Table 3 shows the heavy metal concentration and its distribution in all the sites. The soil sample showed Fe, $\mathrm{Cu}, \mathrm{Zn}, \mathrm{Pb}$ and $\mathrm{Cd}$ levels ranging from 263.00-714.20, $14.80-44.35,15.79-48.42,1.98-6.17$ and $0.08-2.55 \mathrm{mg} / \mathrm{kg}$ respectively. The values of each metal at each sites are relatively higher than that of the control, the high concentration of these metals at these sites could be due to air borne sources from car exhaust fumes depositing lead and other contaminants to the environment, automobile vehicle repair process like filing and soldering of iron rods along with other metals bending processes in the workshop and industrial activities occurring close to the automobile workshops. According to the table, Fe had the highest average concentration, highest concentration of Fe compare to other metals in Nigeria soil have been reported by other researchers (Adefemi et al., 2007; Emmanuel and Edward, 2010). Cd had the lowest average concentration. The total concentration of all the metals analyzed in each site varied as follows $\mathrm{B}>\mathrm{C}>\mathrm{D}>\mathrm{A}>$ control. The highest concentration of all the metals in site B may be attributed to the large size, old age, its location within Oghara metropolis and high volume of wastes at the workshop. T-test was used to indicate significant difference between variables. $\mathrm{P}$-values less than 0.05 were considered statistically significant.

Table.4: Department of Petroleum Resources (DPR, 2002) for Target and Intervention Values for Metals in Soils.

\begin{tabular}{|c|c|c|c|}
\hline \multirow{4}{*}{$\begin{array}{l}\text { Comp } \\
\text { aring } \\
\text { the } \\
\text { conce }\end{array}$} & Heavy Metals & Target values $(\mathrm{mg} / \mathrm{kg})$ & Intervention values $(\mathrm{mg} / \mathrm{kg})$ \\
\hline & Zn & 140 & 720 \\
\hline & $\mathbf{C u}$ & 36 & 190 \\
\hline & Cd & 0.8 & 12 \\
\hline rati & $\mathbf{P b}$ & 85 & 530 \\
\hline
\end{tabular}

on of each metal in each site with DPR (2002) target and intervention values, the levels of $\mathrm{Zn}$ and $\mathrm{Pb}$ found in all the sites were below the DPR target values. The levels of $\mathrm{Cu}$ were above the DPR target value in sites $\mathrm{A}$ and $\mathrm{B}$, but in sites $\mathrm{C}, \mathrm{D}$ and control. The levels of $\mathrm{Cd}$ were above the target value in all the sites except in the control site. From table 4 , it was also observed that all the individual metal analyzed in all the sites showed concentration that were 
below their DPR intervention values (DPR, 2002). There was no DPR target and intervention values for iron perhaps because of its high concentration and distribution in natural or unpolluted soils (Anietie and Labunmi, 2015).

\section{Fractionation and Distribution of the Heavy Metals in the Soil Samples}

Soil samples was fractionated for $\mathrm{Fe}, \mathrm{Cu}, \mathrm{Zn}, \mathrm{Pb}$ and $\mathrm{Cd}$ using the popular Tessier et al. (1979) method. The amount of metal present in an extraction fraction is expressed as a percentage of the total mass of that metal in the entire extraction fraction from a given metal.

Iron: The largest portion of iron was concentrated in the residual fraction (F5) with an average percentage of 22.94 $\%$ in all the sites, similar association of iron to residual fraction was reported by Obasi et al. (2013) and Godwin et al. (2014). This was closely followed by the organic fraction (F4), Fe-Mn oxide fraction (F3) and carbonate fraction (F2) with average percentages of $21.61 \%$, $20.68 \%$ and $20.61 \%$ respectively. The exchangeable fraction $(\mathrm{F} 1)$ had the lowest portion with an average percentage of $14.16 \%$.

Copper: Copper was found mostly in the residual fraction (F5) with a range of $28.18-42.46 \%$, similar association of copper to residual fraction was reported by Godwin et al. (2014). The organic fraction (F4) is next with a range of 10.15-33.62\%, This high concentration of copper in the oxidizable fraction (F4) was due to the stability of copper organic complexes which might be attributed to the high formation constants of organic copper complexes (Obasi et al., 2013). The carbonate fraction (F2), the exchangeable fraction (F1) and the Fe$\mathrm{Mn}$ oxide fraction (F3) has $0.71-28.18 \%, 9.19-18.24 \%$ and $5.41-23.90 \%$ respectively (Figure 3 ).

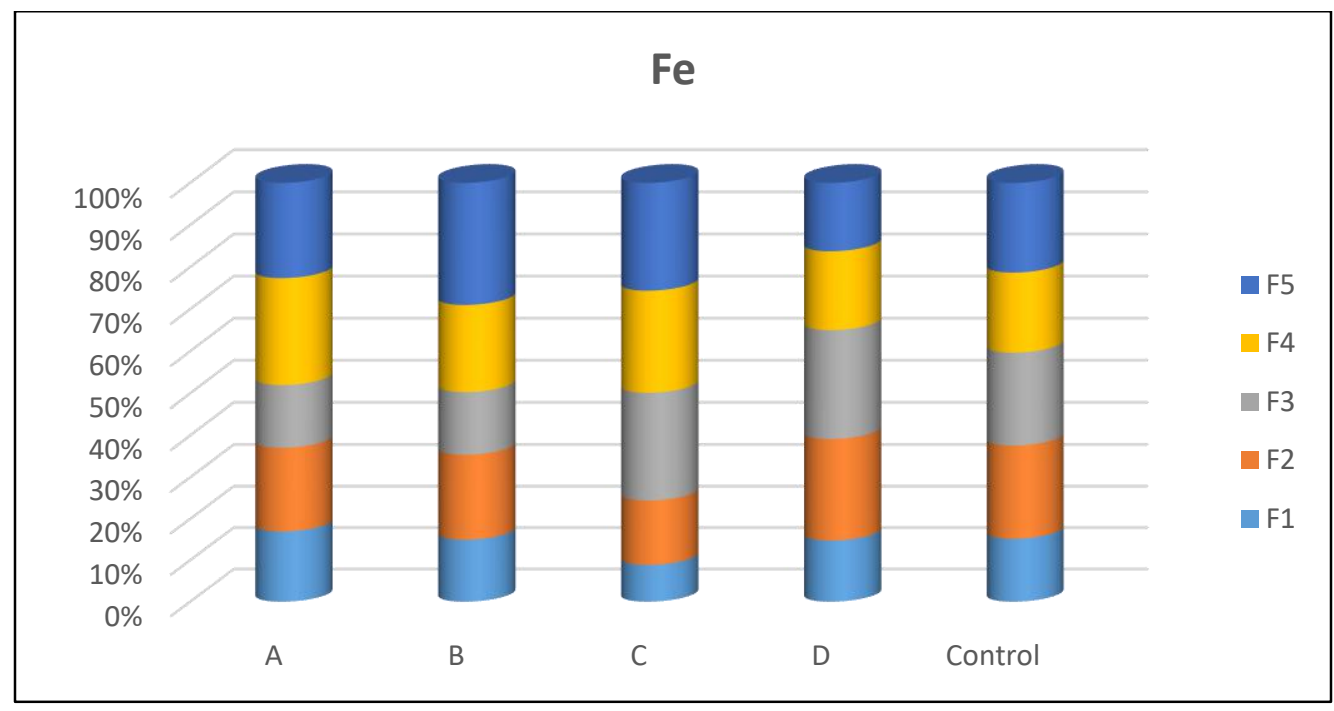

Fig.2: Percentage Concentration of Fe as a Function of Fe Content in the Soil

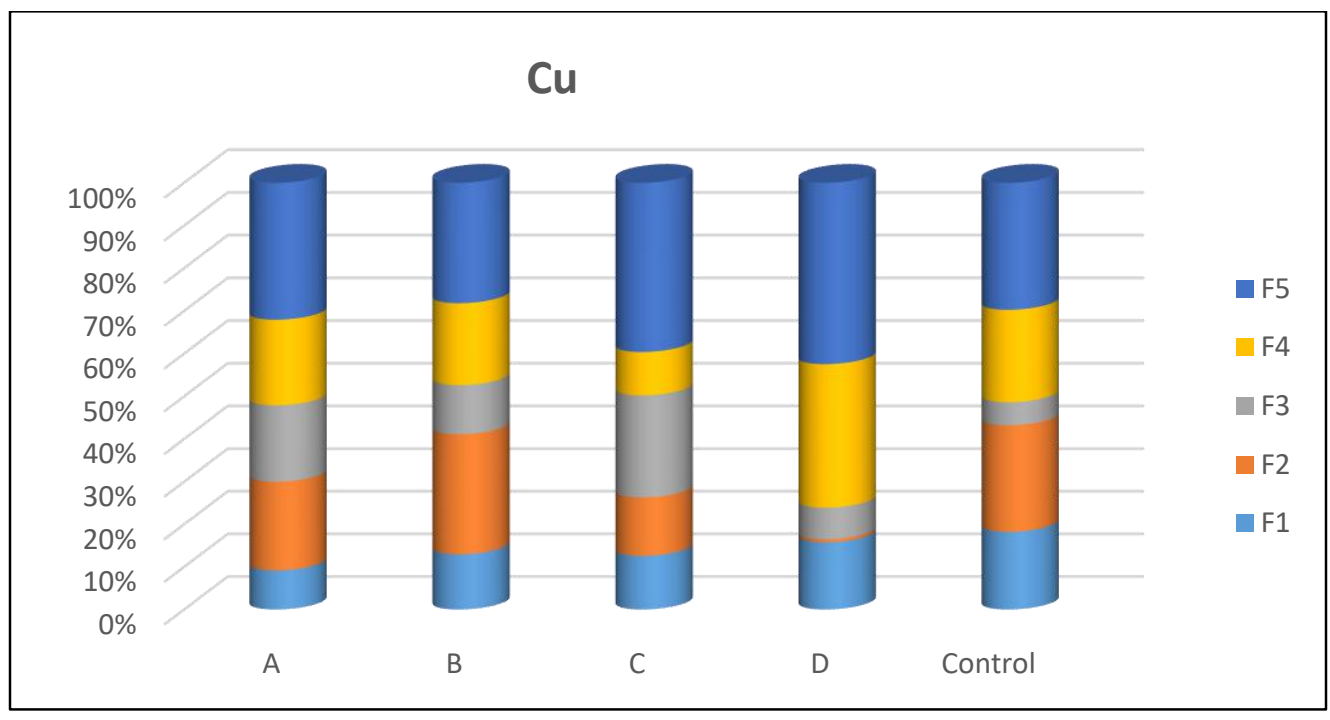

Fig.3: Percentage Concentration of $\mathrm{Cu}$ as a Function of $\mathrm{Cu}$ Content in the Soil 
Zinc: The largest portion of zinc was found in the carbonate fraction F2 with an average percentage of $27.31 \%$. This was closely followed by the residual fraction F5 having an average of $26.82 \%$. the remaining fractions followed the following order $\mathrm{Fe}-\mathrm{Mn}$ oxide fraction > exchangeable fraction > organic fraction.

Lead: Lead was mainly found in the residual fraction F5 ranging from $27.25-95.74 \%$, similar result was obtained by Anegbe and Okuo (2013). The metal may have coprecipitated with various silicate species as a result of their adsorption into the mineral lattice because of the sandy nature of the soil (Manceau et al., 2006). This was followed by the carbonate fraction (0.00-32.10\%), organic fraction (1.60-21.25\%) Fe-Mn oxide bound (2.66$20.44 \%)$ and exchangeable fraction $(0.00-16.85 \%)$.

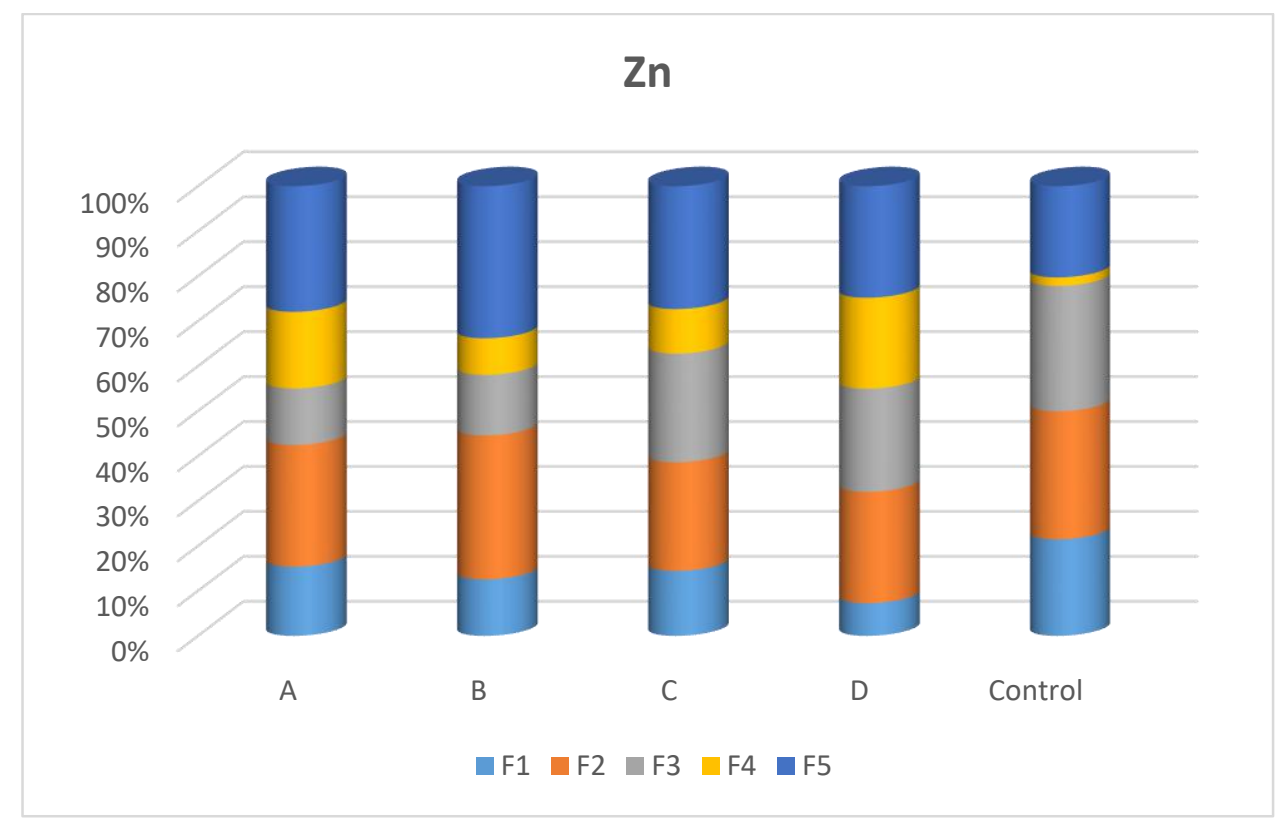

Fig.4: Percentage Concentration of Zn as a Function of Zn Content in the Soil

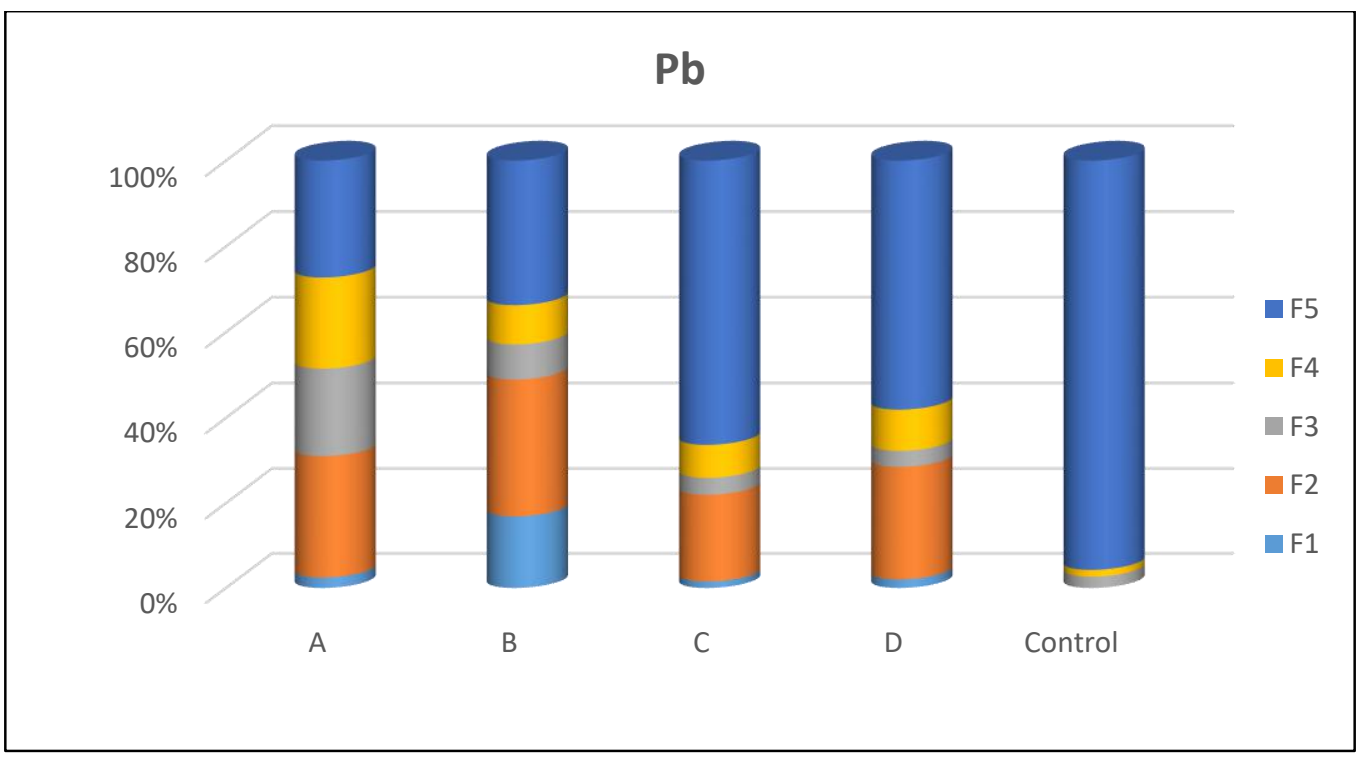

Fig.5: Percentage Concentration of Pb as a Function of Pb Content in the Soil

Cadmium: The greatest amount of cadmium was found in the residual fraction where the range is $35.27-94.24 \%$, similar association of cadmium to residual fraction was reported by Anegbe et al. (2014) in a similar research carried out in Benin City. This was followed by the exchangeable fraction (F1) at a range of $0.00-54.86 \%$. the organic fraction $(\mathrm{F} 4)$, the carbonate fraction $(\mathrm{F} 2)$ and the
Fe-Mn oxide fraction (F3) were in the range of 1.59$12.46 \%, \quad 1.19-10.57 \%$ and $1.09-6.44 \%$ respectively (Figure 6). The minor role of the organic fraction in the speciation of $\mathrm{Cd}$ noted in this present study is consistent with the low adsorption constant of $\mathrm{Cd}$ to organic matter (Yusuf, 2007). 


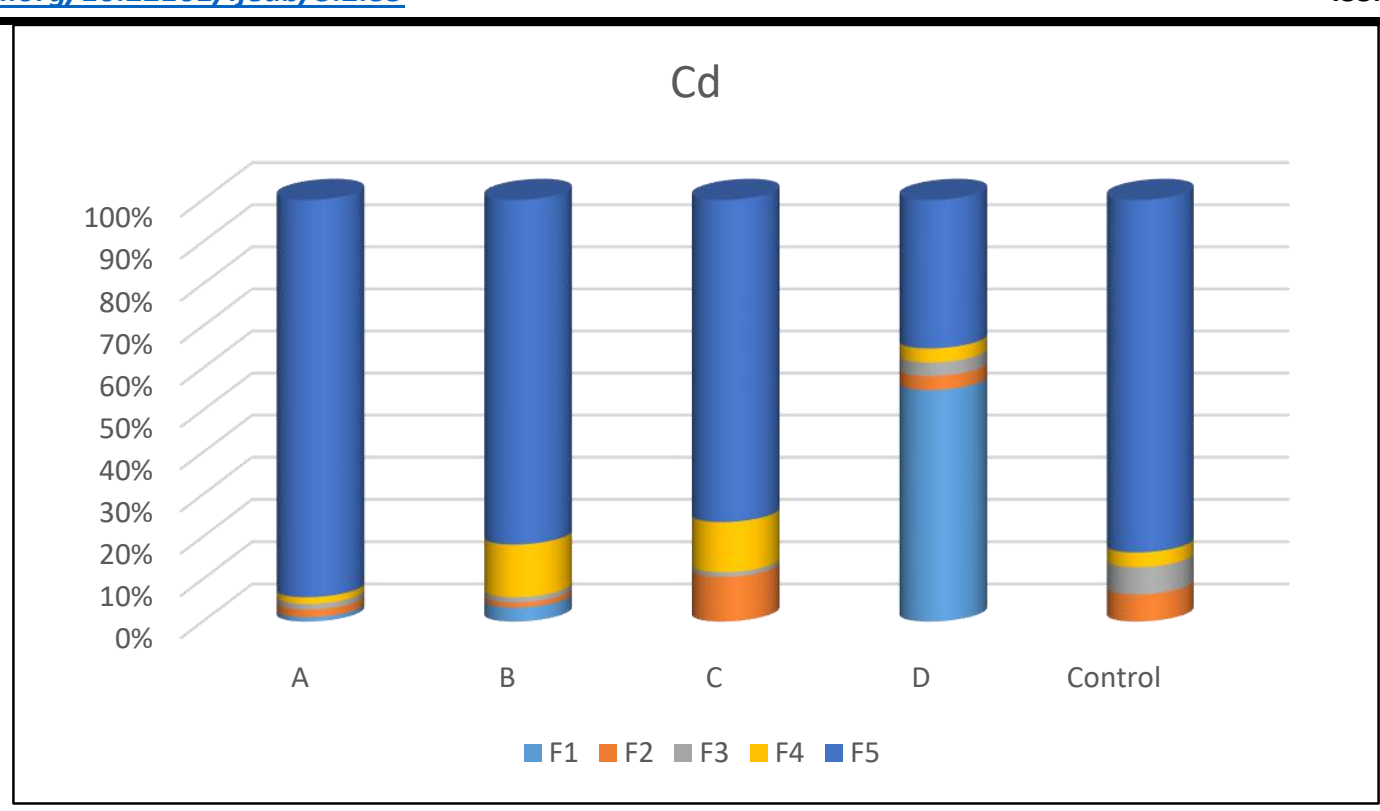

Fig.6: Percentage Concentration of Cd as a Function of Cd Content in the Soil

\section{Mobility Factor}

The operationally defined extraction sequence fractionates the heavy metals in the soil in the order of decreasing solubility. As a result, the exchangeable and carbonate $(\mathrm{F} 1+\mathrm{F} 2)$ fractions which are the early fractions, capture the most reactive and presumably the most mobile and bioavailable fractions (Salbu et al., 1998). The relative index of metal mobility was calculated as a mobility factor (MF) on the basis of the following equation (Kabala and Singh, 2001).

$$
\mathrm{MF}=\frac{\mathrm{F} 1+\mathrm{F} 2}{\mathrm{~F} 1+\mathrm{F} 2+\mathrm{F} 3+\mathrm{F} 4+\mathrm{F} 5}
$$

Where;

$\mathrm{F} 1=\quad$ Exchangeable metal content fraction

$\mathrm{F} 2=\quad$ Metal content bound to carbonate fractions

F3 = Metal content bound to Fe-Mn Oxide Fraction

$\mathrm{F} 4=\quad$ Metal content bound to organic matter fraction
F5 $=\quad$ Residual metal content fraction.

The results obtained from table 5 below showed high mobility factor of the heavy metals within an average range of $16.51 \%-41.54 \%$ for all the sites, which indicates a high lability and biological availability of the metals (Kabala and Singh, 2001; Anegbe and Okuo 2013). The $0.00 \%$ mobility of $\mathrm{Pb}$ observed in the control site indicate that the metal is not bio-available for plant uptake in that site.

According to Wong et al. (2007), high mobility of metals in acidic sandy loam is due to low $\mathrm{pH}$, low clay and low organic matter contents. This means that soil sample with low $\mathrm{pH}$, low percentage of clay and low organic matter content retains fewer metals. Thus, more metals would be released into the soil solution.

Table.5: Mobility Factors (\%) of Fe, $\mathrm{Zn}, \mathrm{Cu}, \mathrm{Pb}$ and $\mathrm{Cd}$ in the Soil Samples

\begin{tabular}{|c|c|c|c|c|c|}
\hline Sites & Fe & $\mathbf{Z n}$ & $\mathbf{C u}$ & $\mathbf{P b}$ & $\mathbf{C d}$ \\
\hline A & 37.11 & 42.47 & 30.02 & 31.06 & 2.85 \\
\hline B & 35.45 & 44.60 & 41.15 & 48.96 & 4.52 \\
\hline C & 24.43 & 38.62 & 26.35 & 21.97 & 10.57 \\
\hline D & 39.19 & 32.05 & 16.49 & 28.54 & 58.19 \\
\hline Control & 37.64 & 49.97 & 43.24 & 0.00 & 6.44 \\
\hline Average & 34.77 & 41.54 & 31.45 & 26.10 & 16.51 \\
\hline
\end{tabular}

\section{Assessment of Metal Contamination}

Contamination Factor (CF)

The level of contamination of soil by metal is expressed in terms of a contamination factor $(\mathrm{CF})$ calculated as:

$\mathrm{CF}=\frac{\text { Cm Sample }}{\text { Cm Background }}$

$\mathrm{Cm}$ Sample $=$ metal concentration in Sample
$\mathrm{Cm}$ Background $=$ metal concentration in background or control Sample. (Fonge et al., 2016)

Where the contamination factor $\mathrm{CF}<1$ refers to low contamination; $1 \leq \mathrm{CF}<3$ means moderate contamination; $3 \leq \mathrm{CF} \leq 6$ indicates considerable contamination and $\mathrm{CF}>6$ indicates very high contamination. 
Table.6: Contamination Factors of $\mathrm{Fe}, \mathrm{Zn}, \mathrm{Cu}, \mathrm{Pb}$ and $\mathrm{Cd}$ in the Soil Samples

\begin{tabular}{|c|l|l|l|l|l|}
\hline Sites & $\mathrm{Fe}$ & $\mathrm{Cu}$ & $\mathrm{Zn}$ & $\mathrm{Pb}$ & $\mathrm{Cd}$ \\
\hline $\mathrm{A}$ & 2.02 & 2.53 & 2.27 & 1.85 & 10.52 \\
\hline $\mathrm{B}$ & 2.72 & 3.00 & 2.49 & 3.12 & 12.72 \\
\hline $\mathrm{C}$ & 2.60 & 2.06 & 2.62 & 2.67 & 12.02 \\
\hline $\mathrm{D}$ & 2.13 & 1.91 & 3.07 & 2.00 & 30.86 \\
\hline
\end{tabular}

From the results of the contamination factors shown above, the soil samples may be classified as moderately contaminated with respect to $\mathrm{Fe}, \mathrm{Cu}, \mathrm{Zn}, \mathrm{Pb}$, and very highly contaminated with respect to $\mathrm{Cd}$ in site $\mathrm{A}$ and site C. The soil samples may be classified as moderately contaminated with respect to $\mathrm{Fe}, \mathrm{Zn}$, considerably contaminated with respect to $\mathrm{Cu}$ and $\mathrm{Pb}$, and very highly contaminated with respect to $\mathrm{Cd}$ in site $\mathrm{B}$. While in site $\mathrm{D}$, the soil samples may be classified as moderately contaminated with respect to $\mathrm{Fe}, \mathrm{Cu}$ and $\mathrm{Pb}$, considerably contaminated with respect to $\mathrm{Zn}$, and very highly contaminated with respect to $\mathrm{Cd}$.

\section{Index of geoaccumulation ( $\left.\mathrm{I}_{\mathrm{geo}}\right)$}

Index of geoaccumulation ( $\mathrm{I}_{\mathrm{geo}}$ ) was used to evaluate the heavy metal pollution by comparing current concentrations with reference (control) values as reported by Bentum et al. (2011).

Igeo $=\log _{2} \frac{C n}{1.5 B n}$

Table.7: Geoaccumulation Index scale

\begin{tabular}{|c|c|c|}
\hline Igeo $_{\text {Value }}$ & Igeo $_{\text {Class }}$ & Designation of sediment quality \\
\hline$>5$ & 6 & Very highly polluted \\
\hline $4-5$ & 5 & Highly polluted \\
\hline$>3-4$ & 4 & Moderately to highly polluted \\
\hline $2-3$ & 3 & Moderately polluted \\
\hline$>1-2$ & 2 & Unpolluted \\
\hline $0-1$ & 1 & Background concentration \\
\hline $0<$ & 0 &
\end{tabular}

Source: Singh et al. (2003).

Where $\mathbf{I}_{\text {geo }}$ is Index of geoaccumulation of the metal, $\mathrm{C}_{\mathrm{n}}$ is the measured concentration of the element in the sample and $\mathrm{B}_{\mathrm{n}}$ is the geochemical background value. As reported in table 7, this index consists of seven scales (0-6) ranging from background concentration to very highly polluted. The interpretation of the results was made based on the scale above in comparison with control sample.

Table.8: Geoaccumulation Index of $\mathrm{Fe}, \mathrm{Zn}, \mathrm{Cu}, \mathrm{Pb}$ and $\mathrm{Cd}$ in the Soil Samples.

\begin{tabular}{|c|l|l|l|l|l|}
\hline Sites & $\mathrm{Fe}$ & $\mathrm{Cu}$ & $\mathrm{Zn}$ & $\mathrm{Pb}$ & $\mathrm{Cd}$ \\
\hline $\mathrm{A}$ & 0.43 & 0.75 & 0.60 & 0.30 & 2.81 \\
\hline $\mathrm{B}$ & 0.86 & 1.00 & 0.73 & 1.06 & 3.08 \\
\hline $\mathrm{C}$ & 0.79 & 0.46 & 0.80 & 0.83 & 3.00 \\
\hline $\mathrm{D}$ & 0.51 & 0.35 & 1.03 & 0.42 & 4.36 \\
\hline
\end{tabular}

From the table above, Site $\mathrm{A}$ is unpolluted with $\mathrm{Fe}, \mathrm{Cu}$, $\mathrm{Zn}$ and $\mathrm{Pb}$, and moderately polluted with $\mathrm{Cd}$. Site $\mathrm{B}$ is unpolluted with $\mathrm{Fe}, \mathrm{Cu}$ and $\mathrm{Zn}$, moderately to unpolluted with $\mathrm{Pb}$, and moderately to highly polluted with $\mathrm{Cd}$. Site $\mathrm{C}$ is unpolluted with $\mathrm{Fe}, \mathrm{Cu}, \mathrm{Zn}$ and $\mathrm{Pb}$, and moderately polluted with $\mathrm{Cd}$. Site $\mathrm{D}$ is unpolluted with $\mathrm{Fe}, \mathrm{Cu}$ and $\mathrm{Pb}$, moderately to unpolluted with $\mathrm{Zn}$, and highly polluted with $\mathrm{Cd}$.

\section{The Pollution Load Index (PLI)}

Generally, pollution load index (PLI) as reported by Harikumar et al. (2009), is as follows:

$\mathrm{PLI}=\sqrt[n]{C f 1 \times C f 2 x C f 3 x C f 4 \ldots \ldots \ldots \ldots \ldots C f n}$

Where, $\mathrm{CF}=$ contamination factor, $\mathrm{n}=$ number of metals

The PLI value of $>1$ is polluted, whereas $<1$ indicates no pollution (Harikumar et al.,2009). 
Table.9: Pollution Load Index (PLI) for the Soil Samples in the Workshop Sites

\begin{tabular}{|c|c|c|c|}
\hline A & B & C & D \\
\hline 2.96 & 3.81 & 3.39 & 3.78 \\
\hline
\end{tabular}

The pollution load index values as calculated for all the workshop sites were greater than 1 (table 9). This is an indication that all sites have metal concentrations which can cause pollution to the environment. The pollution load index value was highest in site B compare to other sites. Hence, site B may cause more pollution to the environment than others.

\section{Correlation Analysis}

All data were analyzed using the SPSS statistical package 21.0. Correlation is significant at the 0.05 level (2-tailed). Correlation is significant at the 0.01 level (2-tailed).

A negative correlation exist between $\mathrm{pH}$ and EC ( $r=-$ $0.920), \mathrm{N}(r=-0.923)$, OC ( $r=-0.956), \mathrm{OM}(r=-0.955)$, and silt $(r=-0.958)$ with a positive correlation on $\mathrm{Mg}$ $(r=0.952)$, CEC $(r=0.954)$ and sand $(r=0.915)$ at 0.05 level of significance. EC negatively correlates $\mathrm{Mg}(r=-$ $0.979)$ at 0.01 level of significance and clay $(r=-0.885)$ at 0.05 level of significance. $\mathrm{N}$ positively correlates $\mathrm{P}$ $(r=0.880), \quad$ OC $\quad(r=0.977), \quad$ OM $\quad(r=0.977)$ and silt $(r=0.991)$ with a negative correlation on sand at 0.05 and 0.01 level of significance respectively. $\mathrm{P}$ positively correlates OC $(r=0.902)$ and OM $(r=0.903)$ at 0.05 level of significance. Ca positively correlates CEC $(r=0.926)$ at 0.05 level of significance. $\mathrm{Mg}$ negatively correlates silt $(r=-0.908)$ at 0.05 level of significance. Na positively correlates $\mathrm{K}(r=0.978)$ and CEC $(r=0.951)$ at 0.01 and 0.05 level of significance respectively. $\mathrm{K}$ positively correlates CEC ( $r=0.888)$ at 0.05 level of significance. CEC negatively correlates OC $(r=-0.901)$ and OM $(r=-$ $0.899)$ at 0.01 level of significance. OC positively correlates OM $(r=1.000)$ and silt $(r=0.975)$ with a negative correlation on sand $(r=-0.972)$ at 0.01 level of significance. OM negatively correlates sand $(r=-0.972)$ with a positive correlation on silt $(r=0.975)$ at 0.01 level of significance. Sand negatively correlates silt $(r=-0.985)$ at 0.01 level of significance.

Table.10: Correlation Coefficient between various Physico-chemical Properties

\begin{tabular}{|c|c|c|c|c|c|c|c|c|c|c|c|c|c|c|}
\hline & $p H$ & $E C$ & $N$ & $P$ & $\mathrm{Ca}$ & $M g$ & $\mathrm{Na}$ & $K$ & $C E C$ & $O . C$ & $O . M$ & SAND & SILT & $C L A Y$ \\
\hline $\mathrm{pH}$ & 1.000 & & & & & & & & & & & & & \\
\hline $\mathrm{EC}$ & $-0.920^{*}$ & 1.000 & & & & & & & & & & & & \\
\hline $\mathrm{N}$ & $-0.923^{*}$ & 0.838 & 1.000 & & & & & & & & & & & \\
\hline $\mathrm{P}$ & -0.738 & 0.548 & $0.880 *$ & 1.000 & & & & & & & & & & \\
\hline $\mathrm{Ca}$ & 0.803 & -0.602 & -0.684 & -0.765 & 1.000 & & & & & & & & & \\
\hline $\mathrm{Mg}$ & $0.952 *$ & $-0.979 * *$ & -0.854 & -0.545 & 0.614 & 1.000 & & & & & & & & \\
\hline $\mathrm{Na}$ & 0.861 & -0.778 & -0.611 & -0.460 & 0.860 & 0.809 & 1.000 & & & & & & & \\
\hline K & 0.741 & -0.647 & -0.452 & -0.358 & 0.852 & 0.671 & $0.978^{* *}$ & 1.000 & & & & & & \\
\hline CEC & $0.954 *$ & -0.843 & -0.809 & -0.705 & $0.926^{*}$ & 0.863 & $0.951 *$ & $0.888^{*}$ & 1.000 & & & & & \\
\hline O.C & $-0.956^{*}$ & 0.825 & $0.977 * *$ & $0.902 *$ & -0.822 & -0.847 & -0.731 & -0.604 & $-0.901 *$ & 1.000 & & & & \\
\hline O.M & $-0.955^{*}$ & 0.823 & $0.977 * *$ & $0.903^{*}$ & -0.821 & -0.845 & -0.728 & -0.601 & $-0.899^{*}$ & $1.000^{* *}$ & 1.000 & & & \\
\hline SAND & $0.915^{*}$ & -0.782 & $-0.988 * *$ & -0.875 & 0.682 & 0.828 & 0.605 & 0.446 & 0.797 & $-0.972 * *$ & $-0.972 * *$ & 1.000 & & \\
\hline SILT & $-0.958^{*}$ & 0.878 & $0.991 * *$ & 0.824 & -0.692 & $-0.908^{*}$ & -0.681 & -0.524 & -0.847 & $0.975^{* *}$ & $0.975^{* *}$ & $-0.985^{* *}$ & 1.000 & \\
\hline CLAY & 0.670 & $-0.885^{*}$ & -0.491 & -0.151 & 0.381 & 0.821 & 0.700 & 0.626 & 0.649 & -0.487 & -0.485 & 0.402 & -0.553 & 1.000 \\
\hline
\end{tabular}

Table.11: Correlation Coefficient between Heavy Metals

\begin{tabular}{|c|c|c|c|c|c|}
\hline & $\mathrm{Fe}$ & $\mathrm{Cu}$ & $\mathrm{Zn}$ & $\mathrm{Pb}$ & $\mathrm{Cd}$ \\
\hline $\mathrm{Fe}$ & 1.000 & & & & \\
\hline $\mathrm{Cu}$ & 0.838 & 1.000 & & & \\
\hline $\mathrm{Zn}$ & 0.821 & 0.615 & 1.000 & & \\
\hline $\mathrm{Pb}$ & $0.969 * *$ & 0.830 & 0.690 & 1.000 & \\
\hline $\mathrm{Cd}$ & 0.453 & 0.264 & 0.862 & 0.316 & 1.000 \\
\hline
\end{tabular}

Fe positively correlates $\mathrm{Pb}(r=0.969)$ at 0.01 level of significance. 


\section{CONCLUSION}

The presence of heavy metals in the environment represents one of the most important environmental hazards. The results show that the soils of the studied areas are contaminated with these metals, especially given the high total concentrations which are gradually being released into the bioavailable forms and subsequently into solution which can lead to absorption into the plants system close to these workshops and cause biomagnification along the food chain. The levels of $\mathrm{Cd}$ and $\mathrm{Pb}$ obtained from this work were found to be less than the values reported by Imasuen and Omorogieva (2013) in a similar research in Benin City. The results of geoaccumulation index revealed that all the sites are polluted with respect to $\mathrm{Cd}$. By and large, mechanic workshop owners should be given stringent rules to operate with full compliance in order to minimize the level of heavy metals introduced to the environment. Furthermore, remediation of the sites should be put into consideration to reduce the amount of total metal concentration in the soil to prevent the absorption of these metals by ground water and other essential plants that are grown close to these sites.

\section{REFERENCES}

[1] Adefemi, O.S., Olaofe D. and Asaolu S.S., (2007). Seasonal variation in heavy metal distribution in the sediment of major dams in Ekiti-State. Pakistan $J$. Nutrition, 6(6): 705-707.

[2] Adriano, D.C. (1992). "Biogeochemistry of trace metals". Boca Raton, Lewis Publisher Florida 514.

[3] Amanda, J.Z. and Weindorf, D.C. (2010). "Heavy metal and trace metal analysis by sequential extraction: A review of procedures". International Journal of Analytical Chemistry 1-7.

[4] Anegbe, B. and Okuo, J.M. (2013): The Impacts of Quarry Factory on the Physico-Chemical properties of Soil and their Potential Health effects on the Surrounding Ecosystem. Nigeria Journal of Applied Science 31: 126-135.

[5] Anegbe, B., Eguavoen, I.W., Oviawe, A.P., Ogbeide,O. and Osayande, A.D. (2014). Profile of heavy metals in soil samples obtained from five auto repair workshops in Benin City Edo State. Biological and Environmental Science Journal for the Tropics, 11(2):84-93.

[6] Anegbe, B., Okuo, J.M. and Okieimen, F.E. (2017). Characterization and remediation of soil cocontaminated by heavy metals and petroleum hydrocarbons. Mostvirtue Benin City, Edo State, Nigeria $1^{\text {st }}$ edition pp 177.

[7] Anegbe, B., Okuo, J.M., Ewekay, E.O. and Ogbeifun, D.E. (2014). Fractionation of Lead-Acid
Battery Soil amended with Biochar. Bayero Journal of Pure and Applied Sciences. 7(2):36-43.

[8] Anietie O. V. and Labunmi L. (2015). Surface Soil Pollution by Heavy Metals: A Case Study of Two Refuse Dumpsites in Akure Metropolis. International Journal of Scientific \& Technology Research, 4(3): 71-74.

[9] Arias M. E., Gonzalez-Perez J. A., Gonzalez-Villa F. J. and Ball A. S. (2005): Soil Health: A new challenge for microbiologists and chemists. International Microbiology 8: 13-21.

[10] Asagba, E.U, Okieimen, F.E. and Osokpor, J. (2007). "Screening and speciation of heavy metal contaminated soil from an automobile spare-parts market, chemical speciation and bioavalability". 19(1): $9-15$.

[11] Bentum J. K., Anang M., Boadu K. O., KorantengAddo E. J. and Owusu A. E. (2011). Assessment of Heavy Metals Pollution of Sediments from Fosu Lagoon IN Ghana Bull. Chem. Soc. Ethiop., 25(2), 191-196.

[12]CUCE, (2007): Cornell University Cooperative Extension; Cation Exchange Capacity (CEC), Agronomy Fact Sheet Series No 22, Department of Crop and Soil Sciences, College of Agriculture and Life Sciences, Cornell University.

[13]DPR-EGASPIN, (2002). Environmental Guidelines and Standards for the Petroleum Industry in Nigeria (EGASPIN), Department of Petroleum Resources, Lagos, Nigeria.

[14]Emmanuel O. F. and Edward O. O. (2010): Evaluation of the Status of Heavy Metal Pollution of Soil and Plant (Chromolaena odorata) of Agbabu Bitumen Deposit Area, Nigeria. American-Eurasian Journal of Scientific Research 5 (4): 241-248.

[15] Fonge, B. A., Nkoleka, E. N., Asong, F. Z., Ajonina, S. A. and Che, V. B. (2016). "Heavy metal contamination in soils from a municipal landfill, surrounded by banana plantation in the eastern flank of Mount Cameroon" African Journal of Biotechnology. 16(25): 1391-1399, 21.

[16] Gbadegesin, A.S. and Abua, M.A. (2011): Variation of Soil Properties on Cassava Production in the Coastal Area of Southern Cross River State, Nigeria. J. Geography and Geol., 3(1):94-103.

[17]Godwin A. E., Imaobong A. E., and Helen S. E. (2014). Speciation, Distribution and Bioavailability of Essential Elements in Waste Impacted Soils Within Niger Delta Region of Nigeria, Annals. Food Science and Technology, 15(1): 162-171.

[18] Harikumar P. S., Nasir U. P. and Mujeebu Rahma M. P. (2009): Distribution of heavy metals in the core sediments of a tropical wetland system; 
International Journal of Environmental Science and Technology, vol. 6, pp. 225-232.

[19] Igwe, J.C., Nnorom, I.C. and Gbaruko, B.C. (2005). Kinetics of Radionuclides and Heavy Metals Behaviour in Soils: Implications for Plant Growth. African J. of Biotechnology, 4(13):1541 - 1547.

[20] Imasuen O. I. and Omorogieva O. M. (2013): Comparative Study of Heavy Metals Distribution in a Mechanic Workshop and a Refuse Dumpsite in Oluku and Otofure Benin City, Edo State, Southwestern Nigeria. J. Appl. Sci. Environ. Manage. Vol. 17 (3) 425-430.

[21] Ipeaiyeda, A.R. and Dawodu, M. (2008). "Heavy metals contamination of topsoil and dispersion in the vicinities of reclaimed auto-repair workshops in Iwo Nigeria". Bulletin of Chemical Society Ethiopia 22:339-593.

[22] Iwegbue, C.M.A. (2007). "Metal fractionation in soil profiles at automobile mechanic waste dumps". Waste Management Research 25:585-593.

[23] Kabala, C. and Singh, B. R. (2001). Fractionation and Mobility of Copper, Lead and Zinc in Soil Profile in the vicinity of a Copper Smelter, $J$. Environ. Qual. 30:485 - 495.

[24] Kabata-Pendias, A. and Mukherjee, A.B. (2007). "Trace Elements from Soil to Human": SpringerVerlag, Berlin.

[25] Karaca A (2004) Effect of organic wastes on the extractability of Cadmium, Copper, nickel and Zinc in Soil. Geoderma 122: 297- 303.

[26] Lawan I. B., Stephen S. H., Goni A. D. and Muhammad T. (2012): Study of Vertical Migration of Heavy Metals in Dumpsites Soil. ARPN Journal of Science and Technology Vol. 2, No. 2, 50-55.

[27] Manceau A. N., Tamora S., Celestre R. S., MacDowell A. A., Sposito G., and Padmore H.A. (2006): Determining trace metal speciation in soils at molecular scale by combine $\mathrm{x}$-ray fluorescence, diffraction and absorption. Environmental Geochemical Group Hillard Hall University of California: 1-4.

[28] Norvell, W.A. (1984). "Comparison of chelating agents for metals in diverse soil materials", Soil Science Society of America Journal 48:1285-1292.

[29] Nwachukwu, M. A., Feng, H. and Alinnor, J. (2010). "Assessment of heavy metal pollution in the soil and their implications within and around mechanic villages". Int. Journal of Environmental Science and Technology 7(2): 347 - 358.

[30] Obasi N. A., Akubugwo E. I., Kalu K. M., Ugbogu A. E. and Okorie U. C. (2013): Toxicological Assessment of Various Metals on Selected Edible Leafy Plants of Umuka and Ubahu Dumpsites in Okigwe of Imo State, Nigeria. Journal of
Experimental Biology and Agricultural Sciences, 1(6): 441-453.

[31] Okiemen, F.E., Emwanta, D.O. and Odilayo, O.O. (2012). Stabilization of heavy Metals in CCA Contaminated Soil. International Journal of Applied Environmental Sciences. 7(2): 215-232.

[32] Okuo, J.M., Eloho, R. and Anegbe, B. (2016). Physico-chemical assessment of Delta South Aquifer - A case study of Oleh and Uzere in Delta State. Nigeria Journal of Applied Science. 34:43-55.

[33] Oviasogie, P.O., Ukpebor, E.E. and Omoti, U. (2006). Distribution of polycyclic aromatic hydrocarbons in rural agricultural wetland soils of the Niger Delta Region. Afr. J. Biotechnol., 5(15): 1415- 1421.

[34]Pecheyran, C., Lalere, B. and Donald, O.F.X (2000). "Volatile metal and metalloid species $(\mathrm{Pb}$, $\mathrm{Hg}$, Se in a European urban atmosphere (Bordeaux, France)". Environmental Science and Technology 34:27-32.

[35] Salbu, B., Kreling, T. and Oughton, D.H. (1998). Characterization of Radioactive Particles in the Environ. Anal. 123: 843 - 849.

[36] Singh, A. K., Hasnain, S. I. and Benerjee, D. K., (2003): Grain Size and Geochemical Portioning of Heavy Metals in Sediments of the Damodar River. A Tributary of the Lower Gang, India. Environmental Geology 39, 90-98.

[37] Tripathi A, and Misra D. R (2012) “A Study of Physico-Chemical Properties and Heavy Metals in Contaminated Soils of Municipal Waste Dumpsites at Allahabad, India" Department of Botany, University of Allahabad, Allahabad, U.P., India International Journal of Environmental Sciences 2:4.

[38] Ugbune, U. and Okuo, J. (2011): Sequential Fractionation and Distribution of Heavy Metals in Soil from Battery Work Sites. Nigeria Journal of Applied Science. 29: 132-141.

[39] Ure, A.M. and Davidson, C.M. (2002). "Chemical Speciation in the Environment". Blackwell, Oxford.

[40] Vogel's, (2008): text book of quantitative chemical analysis. $6^{\text {th }}$ Edition, Prentice Hall, England, pp 277.

[41]Wong, J.W.C., Li, K.L., Zhou, L.X., Selvam, A. (2007). The sorption of $\mathrm{Cd}$ and $\mathrm{Zn}$ by different soils in the presence of dissolved organic matter from sludge. Geoderma 137, 310-317.

[42] Young, M. and Crawford, J.W. (2004). "Interactions and self-organization in the soil-microbe complex". Science 304: 1634-1637.

[43] Yusuf K. A. (2007) sequential extraction of lead, copper, cadmium and zinc in soils near Ojota waste site. Journal of Agronomy 6(2): 331-337. 